\begin{tabular}{ll}
\hline \hline MINING AND METALLURGY INSTITUTE BOR & ISSN: 2334-8836 (Štampano izdanje) \\
UDK: 622 & ISSN: 2406-1395 (Online) \\
\hline \hline
\end{tabular}

\title{
RELATIONSHIP BETWEEN THE ORGANIZATIONAL STRUCTURE AND CULTURE - CASE STUDIES OF THE MINING COMPANIES IN SERBIA
}

\begin{abstract}
Organizational culture and organizational structure have a correlated inter-relationship. Structure determines the behaviors, attitudes, dispositions and ethics that create the work culture. In this paper, the authors analyze the inter-relationship between the organizational structure and culture in the mining companies in Eastern Serbia. Investigation was conducted in two companies, with 138 participants in the survey. The research was conducted at the beginning of 2016. The questionnaires included 50 questions concerning the organizational structure and culture, and were anonymous. The results confirmed a significant correlation between the organizational structure and culture in the investigated organizations.

Keywords: organizational culture, organizational structure, national culture, mining companies
\end{abstract}

\section{INTRODUCTION}

Organizational culture is based on values, expectations, experiences and behaviors of the members of an organization which contribute to the unique social and psychological environment of that organization. It is expressed as an image, interactions with the outside world, future expectations, and is based on shared attitudes, beliefs and customs, written and unwritten rules that have been developed over the time, and are considered valid. It is interrelated with national culture and organizations have been found to operate at the optimal level when there is alignment between national and organizational culture.

Organizational structure depends on the organization's objectives and strategy. It defines how the roles, power and responsibilities are assigned and how hierarchical arrangement of lines of authority, commu- nications, rights and duties are defined in an organization. It regulates control and coordination of information flows among the different levels of management. Organizational culture and organizational structure have a correlated inter-relationship. Structure determines the behaviors, attitudes, dispositions and ethics that create the work culture.

\section{ORGANIZATIONAL CULTURE}

Organizational culture could be defined as a system of assumptions, values, norms and attitudes manifested through symbols which the members of an organization have established and adopted through shared experience, which helps them define the meaning of the outside world and the way they interact with it [1]. Organizational culture defines the character of interpersonal rela-

\footnotetext{
* Faculty of Management in Zajecar, John Naisbitt Unversity Belgrade,Park Suma Kraljevica bb, 19000 Zajecar, Serbia
} 
tions in the organization, improves motivation of employees, defines a leadership style, reduces the number of conflicts and improves the coordination in the organization [2], [3].

Zheng and associates investigated the relationship between the organizational culture, structure, strategy and organizational effectiveness, as well as the role of knowledge management in linking these elements [4]. The results of their study shows that the organizational culture, structure, strategy and organizational effectiveness have noticeable inter- relationships [4]. Management of each organization creates a specific, unique culture. National culture also has a great influence on the creation of organizational culture and management. Employees come to the organization with a certain, already well-defined value system based on their national culture, and which is the foundation of an organizational culture. The influence of national culture on organizational culture and management is established through various studies. During the last few decades, a number of national culture frameworks have been developed, but the most frequently used and replicated has been Hofstede's [5], [6], [7]. Hofstede primarily identified the most commonly used dimensions of national culture: individualism vs. collectivism, power distance, uncertainty avoidance and masculinity vs. femininity [5]. Later, in his further investigations in cooperation with Michael Bond and Michael Minkov, Hofstede identified two additional dimensions: the short-term vs. long-term orientation [8] and indulgence versus restraint [9]. National culture dimensions framework can be used to better understand the organizational culture, the structure and the management in different companies [10]. Paunkovic emphasized the importance of the national culture in defining the optimal or ganizational structure for the implementation of sustainable development projects in Eastern Serbia, as well as in managing sustainable development projects. Studies regarding the organizational and national culture aspects the important published [11], [12].

As well as the national, organizational culture has its own dimension. The IRIC (Institute for Research on Intercultural Cooperation) identified six independent dimensions of practices: the process-oriented versus results-oriented, job-oriented versus employee-oriented, professional versus parochial, open systems versus closed systems, tightly versus loosely controlled, and pragmatic versus - normative [13].

The mainstream successful companies in the world, and in Serbia also, have very recognizable and strong organizational cultures [14], [15]. Strong culture has a positive impact on motivation and loyalty of the employees, makes coordination and control of organization easier, reduces conflicts and enhances creativity [16], [17], [18].

\section{ORGANIZATIONAL STRUCTURE}

Every organization, system or company has its own structure, system of internal links and relationships. Investigation of the organizational structure of a certain company begins by analyzing and defining the general task which should be realized through the overall business, and then by decomposition it into the partial and individual tasks. This decomposition defines a large number of partial tasks that the company performs and according to which the organization should be structured. The appropriate organizational units should be defined in order that the optimal realization of the entire business process is enabled. Organizational structure is the result of the organizational process and is a modus of effectively achieving business goals. It represents the way in which business leaders 
are unified for the realization of certain tasks. A good organizational structure must provide coordination at all levels. When managing an organization, both internal and external factors that create an adequate organizational structure enabling organizational goals to be achieved, must be considered. The most influential internal factors are the organizational culture and strategy [4].

There is a relationship between the organizational culture and structure. Organizational culture has a great impact on the selection and implementation of an organizational structure. A new organizational structure can have an impact on the existing organizational culture consolidating or changing it. Culture is an important factor of organizational structure. Culture is a completely different component which can significantly contribute to the functioning of organization and affects the other mentioned components of the organization, including the structure. Investigations have revealed and partly explained the nature of the impact of national cultures on organizational structure [6], [19], leadership styles [2], [20], managing organizational changes [21], [22], job satisfaction [3], organizational culture [23], human resource management [24]. Organizational models differ from each other according to a degree of formalization and centralization. Different organizational cultures also implicate the use of different organizational models.

\section{RESEARCH}

In order to explore the relationship between the organizational culture and structure in the mining companies, an investigation was conducted on the territory of Eastern Serbia. The study included 138 employees from the companies working in the mining sector, located in the municipality of
Bor. Although management of the both companies has approved the process of investigation, we did not get the permission to reveal the identity of the investigated organizations in publications. For that reason, they will be referred to as: the Company 1 and Company 2. One of the companies is publicly owned, engaged in research and development in mining sector, and the other one is a private company. Total of 138 participants (84 from the Company 1 and 54 from the Company 2) have completed questioners used for this analysis.

The research in these companies was conducted at the beginning of 2016. The investigation was anonymous. The questionnaire consisted of 50 questions, divided into four groups. Participants in the study were asked to grade (1 - not important; 5 very important) 11 questions on a scale of 1 to 5 in the questionnaire. For the purpose of this paper, the groups of questions related to the organizational culture and organizational structure were delineated.

\section{RESEARCH RESULTS}

The general hypothesis for this research was: There is a relationship between the organizational culture and structure.

The following tables represent the average marks, obtained from the questionnaires. The research was conducted in two companies, and the results are presented for both of them.

Regression analysis was used to determine a connectivity between two variables: the organizational culture and organizational structure. Previously, Kolmogorov Smirnov test was performed. The test explored the fulfillment of conditions for parametric statistical tests. The following tables show the regression parameters of the two investigated phenomena (organizational culture and organizational structure). 
Table 1 Organizational culture and structure

\begin{tabular}{|c|c|c|c|c|c|}
\hline $\begin{array}{c}\text { Questions - organizational } \\
\text { culture }\end{array}$ & $*$ & $* *$ & $\begin{array}{c}\text { Questions - organizational } \\
\text { structure }\end{array}$ & $*$ & $* *$ \\
\hline $\begin{array}{l}\text { The employees have the new (better) } \\
\text { ideas for doing business }\end{array}$ & 3.43 & 3.98 & $\begin{array}{l}\text { There is a clear and precise } \\
\text { sharing of work tasks of } \\
\text { employees in the organization }\end{array}$ & 3.54 & 4.41 \\
\hline $\begin{array}{l}\text { The employees are ready to take } \\
\text { risks while implementing their ideas }\end{array}$ & 2.77 & 3.67 & $\begin{array}{l}\text { Activities and work assignments } \\
\text { are grouped }\end{array}$ & 3.67 & 4.24 \\
\hline $\begin{array}{l}\text { The work is organized as a } \\
\text { teamwork }\end{array}$ & 3.77 & 4.52 & $\begin{array}{l}\text { There is a well-defined line of } \\
\text { authority - who is responsible to } \\
\text { whom }\end{array}$ & 4.23 & 4.39 \\
\hline $\begin{array}{l}\text { Management takes into account the } \\
\text { needs of employees }\end{array}$ & 2.69 & 4.44 & $\begin{array}{l}\text { One manager manages a large } \\
\text { number of employees }\end{array}$ & 3.51 & 3.56 \\
\hline $\begin{array}{l}\text { A strong competitive spirit of } \\
\text { employees is expressed }\end{array}$ & 3.25 & 3.31 & $\begin{array}{l}\text { The main strategic decisions } \\
\text { are made by the top management } \\
\text { without participation of managers } \\
\text { from lower levels and employees }\end{array}$ & 3.82 & 3.09 \\
\hline $\begin{array}{l}\text { Due to strongly expressed } \\
\text { competitive spirit, there is sometimes } \\
\text { a lack of cooperation among the } \\
\text { employees }\end{array}$ & 3.24 & 2.65 & $\begin{array}{l}\text { Decisions are made at all levels } \\
\text { of the organization with the } \\
\text { participation of all employees }\end{array}$ & 2.30 & 3.39 \\
\hline $\begin{array}{l}\text { More importance is attached to the } \\
\text { results than the way they are } \\
\text { achieved - the ends justify the } \\
\text { means }\end{array}$ & 3.70 & 2.48 & $\begin{array}{l}\text { The organization provides the } \\
\text { detailed work instructions and } \\
\text { jobs are well-standardized }\end{array}$ & 3.10 & 4.24 \\
\hline $\begin{array}{l}\text { The employees are precise, } \\
\text { analytical and detailed when } \\
\text { performing delegated tasks }\end{array}$ & 3.56 & 4.19 & $\begin{array}{l}\text { The behavior of employees is } \\
\text { precisely defined by the certain } \\
\text { rules and procedures }\end{array}$ & 3.96 & 4.48 \\
\hline $\begin{array}{l}\text { The employees in organization are } \\
\text { encouraged to have respect for others }\end{array}$ & 2.51 & 4.43 & $\begin{array}{l}\text { At last, the employees agree with } \\
\text { what their superior says, although } \\
\text { they do not share his/her thoughts }\end{array}$ & 3.86 & 3.52 \\
\hline $\begin{array}{l}\text { The organization shows loyalty } \\
\text { towards its employees }\end{array}$ & 2.65 & 4.74 & $\begin{array}{l}\text { Employees in the organization } \\
\text { have two or more superiors }\end{array}$ & 3.67 & 3.33 \\
\hline $\begin{array}{l}\text { In this organization, people in } \\
\text { principle have a great respect for } \\
\text { others }\end{array}$ & 2.44 & 4.26 & $\begin{array}{l}\text { There is a good communication } \\
\text { among employees at the same } \\
\text { levels }\end{array}$ & 3.08 & 4.30 \\
\hline
\end{tabular}

* Average mark-Company 1

** Average mark - Company 2

Table 2 Regression parameters of the strength of correlation between two determinants

\begin{tabular}{|c|c|c|c|c|}
\hline $\begin{array}{c}\text { Regression } \\
\text { parameters }\end{array}$ & $\mathbf{R}$ & $\begin{array}{c}\text { Coefficient of } \\
\text { determination }\end{array}$ & $\begin{array}{c}\text { Corrected coefficient of } \\
\text { determination }\end{array}$ & $\begin{array}{c}\text { Standard error } \\
\text { of the estimate }\end{array}$ \\
\hline & 0.572 & 0.327 & 0.319 & 2.77041 \\
\hline
\end{tabular}

Calculated correlation coefficient $(\mathrm{R})$ is 0.572 and it is positive. It means that there is a direct positive correlation between these two investigated phenomena (organizational culture and organizational structure). Taking into account that the value of $\mathrm{R}$ is between
0.50 and 0.75 , it means that there is a moderate to good correlation between organizational structure and organizational culture.

Corrected coefficient of determination is 0.319 , and it can be concluded that the 
organizational culture affects the developing organizational structure in $32 \%$ of the cases. The rest of $68 \%$ of the total variability is not explained by the regression line, and it is under the influence of some other unidentified factors. Small probability of error and statistically significant value of $F$ test shows that the value of coefficient of determination is very important for predicting the variances between variables. Since determination is high, which is statistically very significant, it is further necessary to analyze the shape and strength of a link between the indicators. Parameters from the statistical model, offset and inclination ( $\beta 0$ and $\beta 1$ ), are checked by the T-test. Null hypothesis is set which says that there is no linear link $\mathrm{H} 0: \beta=0$ between the variances of investigated phenomena in the basic set, and two-way alternative hypothesis $\mathrm{H} 1: \beta \neq 0$. The next table shows statistical parameters of the model of regression analysis.

Table 3 Statistical parametric model of regression analysis for the organizational culture and organizational structure

\begin{tabular}{|c|c|c|c|c|c|}
\hline \multirow{2}{*}{$\begin{array}{c}\text { Statistical } \\
\text { parameters of } \\
\text { the model }\end{array}$} & \multicolumn{2}{|c|}{$\begin{array}{c}\text { Non-standardized } \\
\text { coefficients }\end{array}$} & $\begin{array}{c}\text { Standardized } \\
\text { coefficients }\end{array}$ & $\mathbf{t}$ & $\begin{array}{c}\text { Probability } \\
\text { of error }\end{array}$ \\
\cline { 2 - 6 } & $\mathbf{B}$ & Standard error & $\mathbf{B}$ & & \\
\hline Cult/constant & 10.570 & 0.886 & & 11.931 & 0.000 \\
\hline $\begin{array}{c}\text { Org. culture- } \\
\text { inclination }\end{array}$ & 0.531 & 0.084 & 0.572 & 6.310 & 0.000 \\
\hline
\end{tabular}

It can be seen from Table that $\beta_{1}=10.570$. Since this value is not null, regression line can be used for prediction. Probability of the error value is less than adopted (0.05), and the value of the T-test for estimation of inclination is statistically significant. This means that the null hypothesis is rejected, and the alternative $\mathrm{H} 1$ : $\beta \neq 0$ is adopted. Regression line can be used to predict a variation between these phenomena. In the particular case, the equation of regression line is $\mathrm{y}=0.531 \mathrm{x}+10.57$.
The next diagram shows the link between two variables (organizational culture and organizational structure).

The next diagram shows that there is a quantitative correlation between variables of investigated phenomena. Coefficient of determination shows that the organizational structure is the result of existing organizational culture in $32 \%$ of the cases. This confirms the starting hypothesis: "There is a relationship between the organizational culture and structure. "

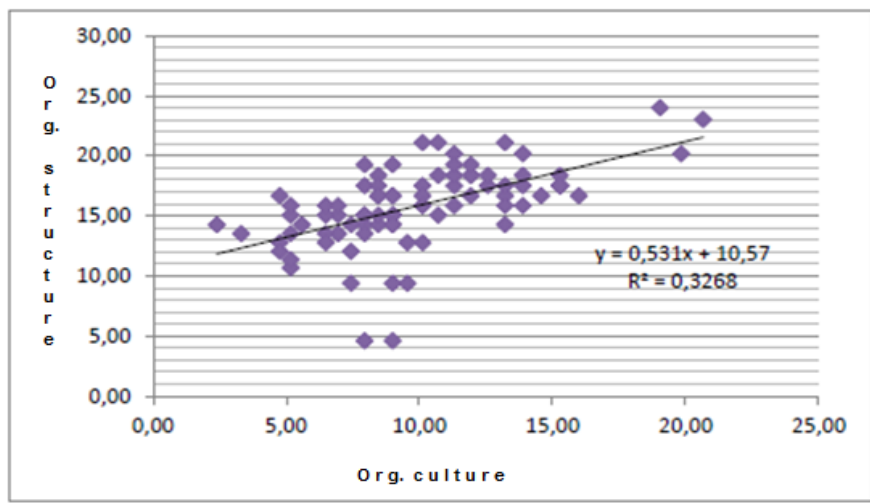

Diagram 1 Dispersion diagram for two variables: the organizational culture and organizational structure 


\section{RESULTS AND DISCUSSION}

Organizational structure is affected by a number of factors such as technology, the activity that an organization performs in the economy, the size of organization and many other factors. Among those factors that influence developing of the organizational structure, a special place is occupied by the organizational culture. The assumptions, values and beliefs of management and employees affect the acceptance or rejection of the certain organizational models. According to [19], a certain organizational culture can contribute to development of the organizational structure, which is unexpected considering other relevant factors.

By comparison the results related to organizational culture of the investigated companies (presented in the tables above), it is evident that the average mark of the respondents from Company 1 does not exceed 3.5, except for the question No.7 ("More importance is attached to the results than the way they are achieved - the ends justify the means") and the question No. 8 ("The employees are precise, analytical and detailed when performing the delegated tasks"). On the other hand, majority of the respondents from the Company 2 gave an average mark higher than 4 , except for the question No. 6 ("Due to strongly expressed competitive spirit, there is a lack of cooperation among employees", and the question No. 7. According to these results, the organizational culture in the Company 2 was recognized by the respondents as more satisfactory in comparison with the organizational culture of the Company 1 .

The average mark of 4.23 for the question No. 25, which belongs to the questions related to organizational structure, shows that there is a well-defined line of authority ("who is responsible to whom") in the Company 1 . However, based on the average mark of 2.3 for the claim that the decisions are made at all levels of the organization with the participation of all employees, it can be concluded that the structure of this organization is quite centralized. On the other hand, the average marks for the same questions in the Company 2 is 3.5 and 4.5 so the conclusion could be that this organization has a clearly defined formal structure where behavior of employees is precisely defined by the certain rules and procedures, but also that the employees have possibility to take part in some business related decisions. The high average marks show that there is a good communication among employees at all levels.

The existence of a direct positive correlation between the organizational culture and organizational structure is confirmed by the correlation coefficient of 0.572 . Coefficient of determination shows that the organizational structure is the result of existing organizational culture in $32 \%$ of the cases.

Organizational culture primarily affects two dimensions of organizational structure the level of formalization and level of centralization of decision-making. In this case, the research has shown that the organizational culture of the second com-pany organizational culture was recognized by the employees as more satisfactory in comparison with the organizational culture of the Company 1 . The work in the second company is organized as a teamwork, managers pay attention to the needs of the employees, and employees have respect for their colleagues. Based on this, it is expected that the organizational structure of the second company should be less centralized. The obtained data justified the expectations, and it is shown by the average marks for the claim: the main strategic decisions for the company as well as the other decisions related to the business of the organization are made by the top management without participation of managers from lower levels and employees. As far as the first organization is concerned, the 
average mark for this claim is almost 4.0 (3.82), and for the second organization is 3.0. Based on the obtained average marks and on correlation coefficient and coefficient of determination, obtained by the regression analysis, the starting hypotheses that there is a correlation between the organizational culture and structure is confirmed.

Nevertheless, the average mark of 3.0 for the claim that the main, strategic decisions for the company, as well as the other decisions related to the business of the organization, are made by the top management, without participation of managers from lower levels and employees, shows an indecisiveness of the employees of the second company. It could be interpreted as if the employees from the second company did not want to make a statement about this claim, and it shows that the structure of the second company is also centralized. These results corroborate Hofstede's research on the national culture dimensions [12], [13]. According to Hofstde, the nationnal culture of Serbia is characterized by the high Power Distance Index (PDI), and consequently, the organizations are generally expected to have a centralized form of organizational structure.

\section{CONCLUSION}

The mining companies in Serbia are in a very demanding position. Their business is characterized by a work of great complexity, obsolete and complex organizational structure, as well as a hardly adequate management practice, work and functioning. This situation could be improved creating such an organizational culture that supports the adequate organizational structure. Adequate structure and culture alignment could enable companies to become more profitable and improve the market position. It is necessary that the management of these companies understand this complex inter-relationship between the organizational structure and culture, as well as the national culture influence on organizational performance.

\section{REFERENCES}

[1] Robbins, S. P., \& Judge, T. A. (2013). Organizational Behavior, $15^{\text {th }}$ Eden.

[2] Nazarian, A., \& Atkinson, P. (2013). Impact of Culture on Leadership Style: The Case of Iranian Organisations. World Applied Sciences Journal, 28(6), 770-777.

[3] Lok, P., \& Crawford, J. (2004). The Effect of Organisational Culture and Leadership Style on Job Satisfaction and Organisational Commitment: A Cross-National Comparison. Journal of Management Development, 23(4), 321-338.

[4] Zheng, W., Yang, B., \& McLean, G. N. (2010). Linking Organizational Culture, Structure, Strategy, and Organizational Effectiveness: Mediating Role of Knowledge Management. Journal of Business Research, 63(7), 763-771.

[5] Hofstede G., (1980.) Culture's Consequences: International Differen-ces in Work-Related Values. Thousand Oaks, CA: SAGE Publications.

[6] Hofstede, Geert (2001.) Culture's Consequences: Comparing Values, Behaviors, Institutions, and Organizations Across Nations. Thousand Oaks, CA: SAGE Publications.

[7] Hofstede, Geert (1996.) Riding the Waves of Commerce: A Test of Trompenaars' "Model" of National Culture Differences. International Jour-nal of Intercultural Relations 20(2):189-98.

[8] Hofstede, G. and Bond, M.H. (1988) 'The Confucius Connection: From Cultural Roots

[9] Hofstede, G., \& Minkov, M. (2010). Long-Versus Short-Term Orientation: New Perspectives. Asia Pacific Business Review, 16(4), 493-504. 
[10] Paunković J., Baltezarević V., Cvetković A (2011) “Optimal Organizational Design of Sustainable Development Projects in East Serbia", National Conference with International Participation Fifth Edition, Sibiu, Alma Mater University, 24 - 26 March 2011.

[11] Paunković, J. (2014) "Educational Programs for Sustainable Societies Using Cross-Cultural Management Method." Global Sustainable Communities Handbook: Green Design Technologies and Economics (2014): 387 Butterworth Heinemann Imprint of Elsevier, Elsevier Copyright (c) 2014.

[12] Paunkovic, J., Paunkovic, N. (2015) "eHealth for Sustainable Health Care in Serbia" in: The Green Industrial Revolution, 491- 513, Butterworth Heinemann imprint of Elsevier Copyright (C) 2015 Elsevier Inc

[13] http://geerthofstede.com/culture-geerthofstede-gert-jan-hofstede/6d-modelorganizational-culture//02.12.2017./

[14] Ritchie, M. (2000). Organizational Culture: An Examination of its Effect on the Internalization Process and Member Performance. Southern Business Review, 25(2), 1.

[15] Jovanović V. (2016) Organizational Learning as a Factor for Sustainable Management of Companies, Faculty of Management Zaječar, Doctoral Dissertation (in Serbian)

[16] Thokozani SBM (2017) Strong vs. Weak Organizational Culture: Assessing the Impact on Employee Motivation. Arabian J Bus Manag Review 7: 287.

[17] Körner, M., Wirtz, M. A., Bengel, J., \& Göritz, A. S. (2015). Relationship of Organizational Culture, Teamwork and
Job Satisfaction in Interprofessional Teams. BMC Health Services Research, 15(1), 243.

[18] O'Neill, J. W., Beauvais, L. L., \& Scholl, R. W. (2016). The Use of Organizational Culture and Structure to Guide Strategic Behavior: An Information Processing Perspective. Journal of Behavioral and Applied Management, 2(2).

[19] Conţiu, L. C. (2011). The Influence of Culture on Organizational Structures in Romania. Studia Universitatis Petru Maior-Philologia, 10.

[20] Dikko, A. Y. (2017) Impact of Leadership Style on Organisational Commitment: The Role of National Culture in Nigerian Universities. Asian Journal of Multidisciplinary Studies, 5(5).

[21] Aldulaimi, S. H., \& Sailan, M. S. (2012). The National Values Impact on Organizational Change on Public Organizations in Qatar. International Journal of Business and Management, 7(1), 182.

[22] Aldulaimi, S.H., Sailan, S.B., (2013) The Relationship Between National Culture and Organizational Commitment to Change and Mediating Effect of Readiness for Change, Journal of Management (JOM), Volume 1, Issue 1, July-December (2013)

[23] Nazarian, A., Atkinson, P., \& Foroudi, P. (2017). Influence of National Culture and Balanced Organizational Culture on the Hotel Industry's Performance. International Journal of Hospitality Management, 63, 22-32.

[24] Đorđević, B. (2016). Impact of National Culture on International Human Resource Management. Economic Themes, 54(2), 281-300. 